\title{
Historein
}

Vol 3 (2001)

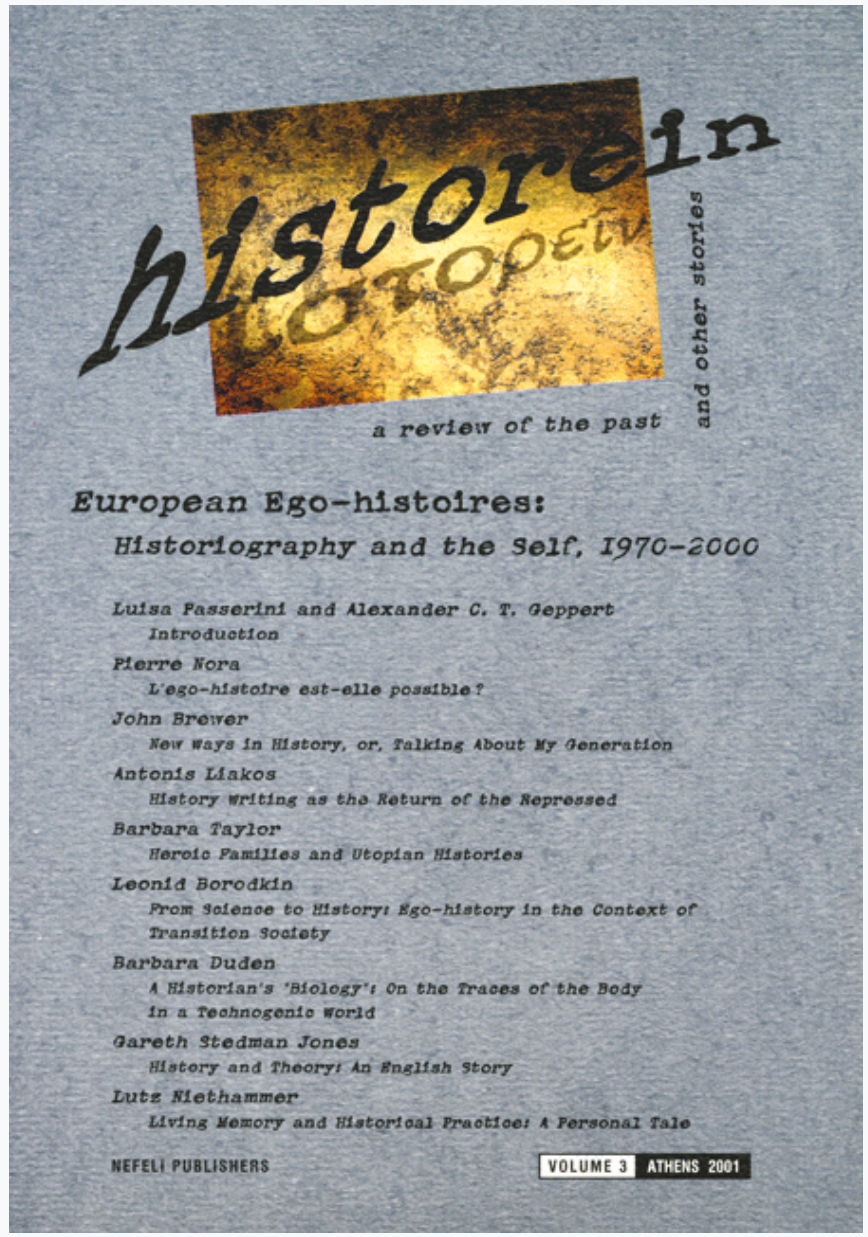

\section{Historians in Flux: The Concept, Task and Challenge of ego-histoire}

Luisa Passerini, Alexander C. T. Geppert

doi: $10.12681 /$ historein.96

Copyright @ 2012, Luisa Passerini, Alexander C. T. Geppert

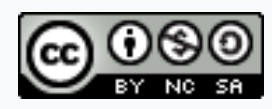

This work is licensed under a Creative Commons Attribution-NonCommercialShareAlike 4.0.

\section{To cite this article:}

Passerini, L., \& Geppert, A. C. T. (2002). Historians in Flux: The Concept, Task and Challenge of ego-histoire. Historein, 3, 7-18. https://doi.org/10.12681/historein.96 
The historian, before he begins to write history, is the product of history. [...] It is not merely the events that are in flux. The historian himself is in flux. [...] Before you study the history, study the historian.

Edward Hallett Carr ${ }^{1}$

\section{Historians in Flux:}

\section{The Concept, Task and Challenge of Ego-histoire}

\section{The Concept of Ego-histoire}

In 1987 the Essais d'ego-histoire were published in Paris, originating from the idea by Pierre Nora that "historians could try to be the historians of themselves." It was a "tentative de

\section{Introduction}

laboratoire," as Nora wrote in his introduction to the book, its aim being to produce a new genre for a new age of historical consciousness. The old age had been that of canceling the writing subject of the historian, of dissimulating personality behind knowledge, and of escaping to other epochs, and had been dominated by illusions of impersonality and objectivity. Now, instead, the time had come to transform the existential involvement of the historian into an analytical tool capable of documenting and demonstrating some of the basic procedures of writing history. It was now both possible and necessary to thematize the link between the history that one makes and the history that makes us: "On n'est pas historien un peu."

Some fifteen years later, these aims are still relevant; indeed, even more so. The historical profession is imbued with presuppositions which die hard, such as the conviction regarding the empirical nature of research, which supposes that little theoretical reflection is needed to produce a good history text. Again, the teaching of history is still largely inspired by 
positivistic assumptions, and the impact of cultural studies on history has not always led to methodological self-awareness either. The need to go further in the exploration and experimentation of ego-histoire is strengthened by the increasing tendency towards autobiographical writing done not only by historians but also by other practitioners of the social sciences, especially anthropologists, the pioneers in this field.

However, it is precisely this overlap between autobiography and ego-histoire which must be dispelled. Some of the ensuing confusion that came about as a result of this mix in genres was already visible in the book edited by Nora, in spite of the fact that he excluded - as possible models for the new genre - autobiographies, confessions, "professions de foi abstraite," and wild psychoanalyzing (a genre present in the 1970s, mostly in its oral form). There will always be traces of autobiography in ego-histoires, since it is important that these also bear witness to the historiographical procedure of transforming a topic into a historical object. What is to be regretted is that the existing ego-histoires, including those we are presenting here, do not pay sufficient attention to the question of how one documents the ego-historical writing, other than basing it on one's own memories, as we will see further on.

Ego-histoire, as we understand it, is a mainly methodological enterprise, aiming to establish a ground of meta-historical reflection. Metaphorically, this ground can be said to be situated half way between - and to connect - the practice of history with the philosophical and existential systems of thinking held by historians. It is the area where the selection of objects, contents, sources, and methods that will constitute the historical narrative, is made. This ground is by no means based merely on the individual; it is always also determined by forms of collective belonging such as race, gender, generation, and nation. The difficulty and the interest of ego-histoire lie precisely in the effort of self-reflection which it requires, where the self must be recognized as a combination of both the individual and the collective.

Our collection of essays is inspired by the term coined by Nora and the book edited by him, as well as by some new preoccupations, which we will set out in the following sections of this introduction. Additionally, our project has been inspired by other examples of ego-histoires (before and after Nora's book), which took this form although not called by this name. In a footnote to his 1987 introduction, Pierre Nora quoted a number of "prototypes," from Ariès to Besançon, relating to ego-histoire. ${ }^{3}$ We have found, however, that the genre has a much longer, not exclusively French past. While Nora coined the term, labeled the genre and further developed its methodological dimension, he neither invented the procedure nor was he the first to ask the question. Even if only loosely connected to this enterprise, there is a tradition of intellectual or Gelehrtenautobiographie dating back to the middle of the eighteenth century at least, coinciding with what Günter Niggl calls a "new will to self-representation." Here, a scholar at the end of his career tried to give evidence of his intellectual and academic development alike, usually in the form of what can be called an intellectual "will." Even before Jean-Jacques Rousseau's famous Confessions (written in 1766/70, but only brought out posthumously in 1782), scholars 
published self-portraits in which they should prove intellectual independence, mental creativity and academic effectiveness, often with the idea of passing something on to future colleagues. These were no longer histories of the religiously awakened soul but, rather, stories of the scholarly, secularized self and its career in public life, which could sometimes take the form of intellectual adventure stories. ${ }^{4}$

More specifically with regard to historians' "confessions," two volumes entitled Die Geschichtswissenschaften der Gegenwart in Selbstdarstellungen were published by Sigfrid Steinberg in 1925 and 1926 respectively. These formed part of an entire series of scholarly selfportraits from various disciplines, such as law, macroeconomics, history of art, philosophy and others, and included more than a dozen essays of exclusively male, comparatively conservative and mainly medieval historians. The collection also contained essays by a number of international scholars, such as George Peabody Gooch. ${ }^{5}$ In the late 1940 s, this approach was explicitly taken up and developed by Nikolaus Grass, a young Austrian professor of the history of law, who collected self-portraits of twenty Austrian historians over sixty years old, subsequently publishing them in two volumes entitled Österreichische Geschichtswissenschaft der Gegenwart in Selbstdarstellungen. Rather than speaking of "autobiographies" or "memoirs," both Steinberg and Grass chose to label the pieces as "autoergography." Grass enthusiastically explained the usefulness of such a collection as rendering the humanities more human: "Gelehrte, die wir bisher vielfach nur aus ihren Werken kennen, treten hier als lebendige Menschen vor uns!"

However, even within a French historiographical context, precursors asking the same set of questions can be found. Already in 1972, Fernand Braudel, one of the central figures of the Annales, had published a short self-portrait, almost an ego-histoire avant la lettre, entitled "Personal Testimony" in which he tried to reply to the very ego-historical question, identical in its double perspective: "How was I shaped as a historian? And how can a historical account of the development of the Annales School be taken as an example of the particular circumstances of contemporary French historiography?" In other words, "to consider myself in some fashion as an object of history" - or, to use again Nora's later phrasing: "des historiens cherchent à se faire les historiens d'eux-mêmes." It is in ego-histoire that the historian's object and subject conflate. Only here, the subject matter and his or her persona become one and the same - already in itself quite a tricky task.

These, and other attempts by historians to historicize their histories can be contextualized even further. Autobiographical gestures or larger moves by historians are more common than might be assumed at first sight. First of all, since Herodotus, book prefaces have been the place par excellence where historians are entitled to speak of themselves, and even to use the first person singular. In recent years, however, it has become evermore fashionable to either begin or to conclude historical monographs with extensive, much more explicit autobiographical notes, locating and explaining the author's personal position towards and within his or her subject matter. ${ }^{8}$ Secondly, historians with as diverse interests as Carolyn Kay Steedman and George Mosse, Peter 
Gay and Sebastian Haffner, Saul Friedländer and Annie Kriegel have all presented different forms of writing that - in one way or another - all feature at least certain autobiographical elements. ${ }^{9}$ Thirdly, special occasions or the presentation of awards commonly present welcome opportunities for publishing so-called Festschriften which then, in turn, sometimes contain self-portraits of historians and other writings of a primarily commemorative character. Fourthly, various projects are aimed at fostering the self-understanding and self-historicization of a particular discipline, such as history or sociology. In order to cultivate this "stock-taking" interest the American Council of Learned Societies inaugurated a series of lectures in 1983. Each year in the "Charles Homer Haskins Lecture" an eminent humanist is asked to reflect on and reminisce about a lifetime of work as a scholar, on the motives, the satisfactions and the disappointments of the "life of learning." Prominent historians such as Lawrence Stone, Carl E. Schorske and Natalie Zemon Davis have been invited to speak. ${ }^{10}$ Other projects, such as a collection of essays written by German refugee historians in British exile edited by Peter Alter, and a number of interviews undertaken by a group of young historians from Berlin have helped, for example, to understand the history of the historical profession in a more immediate political way, particularly the Third Reich. ${ }^{11}$ Last but not least, interviews with historians are even more common; frequently they entail autobiographical and ego-historical elements. Journals such as the Radical History Review, the Hispanic American Historical Review, The Historian and the Österreichische Zeitschrift für Geschichtswissenschaften regularly feature interviews that often concentrate on the personal development or intellectual career of the historian in question. ${ }^{12}$ In addition, since 1985, the Institute of Historical Research in London has released a series of almost thirty video interviews with British senior historians undertaken by younger colleagues active in the same field. Here as well, discussions often focus on the influences that have shaped their work and incorporate reflections on their writing and careers alike. ${ }^{13}$ Taken together, these examples clearly demonstrate that there is a more widely practiced and accepted intellectual background lurking behind this seemingly overtly postmodern, purely self-reflexive project than might be obvious at first sight.

\section{The Task and the Sample}

How, then, do these autobiographical "gestures" differ from the eight ego-histoires presented in this volume? The incentive to pick up and further develop the idea of ego-histoire originated in the course of a series of talks organized by researchers at the European University Institute (EUI) in Florence under the title "Le Métier d'historien" in the years 1997-99. Two of the eight papers included in this present collection, by John Brewer and Lutz Niethammer, are based upon oral presentations originally given in that series. Some of these talks opened up insights into the various characteristics of the historical profession in a particular era. We felt that this approach should be extended to other historians. In order to contribute to the ongoing exploration of the role of the self in the production of history, we then organized a series of "European Ego-histoires" over the course of three semesters from spring 2000 onwards. The six talks given in this second series at the EUI generated the present papers. 
The ego-histoires collected by Pierre Nora were all by French historians, mostly born during the interwar years. We decided to give a strong European slant to our enterprise and to invite historians from various countries. Since the genre of ego-histoire seemed to be better developed in France and Germany than in other European countries, we made a point of having various speakers from Great Britain (although one of them, Barbara Taylor, was born in Canada - an indication of the multiplicity of European derivations). At the same time we were keen to include historians from Eastern and Southern Europe. We ended up choosing one Greek, one Russian, one French, two German and three British historians, two of whom are female and six male. Our second aim was to invite historians belonging to the generation that we believed had played a crucial role in changing the historical paradigm in recent decades. Therefore, we selected historians born between 1935 and 1950, who were thus members of the political generation of 1968, which coincided with the advent of the "New Social History" around 1970. We also chose to consider only the fields of modern and contemporary history, not including any scholar working on the period before the French Revolution.

In general, however, our selection of these scholars was not based primarily on their geographical place of origin but on our interest in their work. "Historians have usually been very cautious about self-revelation," William H. McNeill noted in an interview, "but the self behind the opus is always interesting, if the works themselves are interesting." ${ }^{14}$ Translocations into the subjective are always difficult to defend. However, in this case, our experience clearly confirms McNeill's statement. Of course, no representativeness can be claimed for the resulting group, given the "sample's" small number and the fact that some invitees could not accept our invitation - either because they felt they lacked the time needed to set about such a challenging task, or because they considered it principally impossible to fulfill. ${ }^{15}$

The selected scholars received a standardized letter of invitation in which we asked them to reply to the following questions: "We are interested in analyzing connections between personal interests, individual and generational life choices and styles on the one hand, and your work on the other. We want you to reinterpret and reflect on your contribution to historiography from a personal point of view. How (and why) did your interests in history and historical research develop the way they did? What were the crucial stimuli, decisions and turning-points? In retrospect, can you identify a common strand, a general theoretical or methodological approach, or a connecting political, social, cultural or economic theme in your œuvre? And how do you view your prior and current relationship with the historical profession in general? Last but not least, why history? What made you devote a considerable part of your lifetime to the study of history? Thus, we are not asking for an entire intellectual autobiography, a genuine Gelehrtenautobiographie, but rather an essay which reflects on the decisions, circumstances and conditions 'in life' that affected your personal and professional choices in historiography and thus possibly the profession at large." 
By asking this set of questions, we intended to cover five different areas:

- Theme: Why did these historians choose history in the first place, and subsequently their specific subject matter? How did their interests in this particular field develop and change over the course of their careers?

- Methodology: At what stage of their career did they develop their methodological tools, and how did their preferences for those methods develop? And again, how did these methods and preferences then change over the years?

- Professional concerns: When, how and why did they decide to become professional historians? Did they follow a vocation - or was it, rather, an avocation that simply made this decision happen? In addition, given that these texts have been written by historians of international repute, they should give perceptive insights into the self-understanding of the historical profession at large, especially when read together.

- Introduction to the writing of history: Both with a view to the current state of the art in historiography and with a generation of young academics in mind, these self-portraits can be read as short introductory pieces to a number of sub-disciplines and particular fields of study. "Before you study the history, study the historian," E. H. Carr has suggested. Seeing how these wellknown historians want their own work to be approached, read and categorized should give students historiographical meta-knowledge.

- Politics: According to our contributors, what is the historian's role and importance in contemporary public life? How do historians themselves understand their relationship with the public and society at large - especially bearing in mind that they are all mainly financed by public funds?

In this context, it is important to stress once again that we were very keen to give priority to questions of "work" over "life" or "ego," even if we asked all ego-historiens to view their contribution to historiography from a highly personal and subjective perspective, namely, through the prism of their lives. It goes without saying that we carefully avoided asking anyone for intimate details of their private lives. By inviting these eight innovative, well-established and enormously active scholars to present their individual work-biographies to a wider audience, we hoped to collect both informative and critical self-portraits of historians that could simultaneously help us to understand the role of the self in the writing of history and the historian's position in the public sphere.

\section{The Challenge of Ego-histoire}

The participants were free to consider our questions simply as a guide, and this is what they did, showing a remarkable variety of approaches as well as some convergences. A complete and exhaustive reading of these fascinating texts obviously cannot be provided in this introductory essay. Nonetheless, in the following, we shall present at least some perspectives on how to read and analyze these life stories and self-portraits. 
The ego-histoires collected in this volume indicate at least two major directions of thought. As both Gareth Stedman Jones and John Brewer agree, decisive changes in the understanding of history occurred in the 1950s and early 1960s, which the generation of that period translated into historiographical practice during the following three decades. This change concerned the relationship between the subject and object of historiography, reflecting an awareness of the subject's presence in historical writing. It also involves an awareness of the link between the political and the cultural, understood as direct in the 1960s, but seen as increasingly mediated starting in the late 1970s. The historian's work is therefore understood as very specific, with political reverberations, but not as directly political. It will be clear by now that we invited only "progressive" historians to reflect on their experiences. Other, more traditional, or rather "orthodox" historians were not included in this sample.

Moreover, the personal and the professional/public spheres intertwine in these narratives, sometimes in a very moving, always very suggestive way. The "ego's" presence in these texts differs to a considerable degree. In some cases, it is constantly there; in others, however, the private remains in the background, largely hidden behind the historian's work. These stories demonstrate to what extent the historical profession has widened to include public issues and duties, how much the boundaries between the private and the public have moved in the last thirty years, and how the private has to some extent become publicized. The relationship between the public and the private is a good ground for illustrating the simultaneous presence of the autobiographical and the meta-historical dimension in ego-histoire. Barbara Duden, for instance, not only reveals the personal and autobiographical roots of her own "growing into a historian of the body"; she also shows how her choice of topic and way of treating it are imbued with meta-historical assumptions about her own relationship with her object.

Memory appears to have been the main source of these ego-histoires, although some historians introduced private photographs and subsequently we asked others to follow their example. Leonid Borodkin even brought school reports, medals and other personal diplomas from Moscow. However, interestingly enough, none of the scholars seemed inclined to reflect on other possible sources for documenting the effort of ego-histoire. Only one of them, Lutz Niethammer, expresses a certain skeptical criticism and methodological restraint with regard to the overall feasibility of the task. He effectively challenges the concept by resisting being the historian of himself and putting the reader into that position. This might rather suggest that historians today strongly feel the need to reflect on and introduce some sort of theoretical and methodological concern to their work, meaning that they seize on the opportunity to do so when it is offered to them, momentarily suspending their usual concerns with sources. Here again, as in Nora's book, we witness the striking alternation between and combination of autobiography and ego-histoire. None of the contributors tries to apply his or her preferred historiographical method to his or her own life story. Teaching and students are also mentioned only rarely. 
What seems promising in our collection is the potential comparative approach, if more ego-histoires were to be collected. Themes of this comparison could be: the various meanings of "public" in different countries; the existence of national and international networks of historians, largely generationally based; the various national forms of the politicization of history, a process that started in the 1970s and continued in different ways in the 1980s, when it moved towards the cultural. In that respect, Leonid Borodkin's contribution is of utmost interest, as he calls our attention to the fundamentally different working conditions in both pre-and postPerestroika Russia that had obvious, but nonetheless far-reaching effects on historical research. In addition, cross-disciplinary comparisons might show the different degrees to which personality and scholarly practice are integrated into other fields. ${ }^{16} \mathrm{~A}$ bibliography added at the end of this volume (cf. pp. 173-178) is aimed at fostering future research in this direction.

Are the historians presented in our collection those "who made it" and are their ego-histoires therefore necessarily success stories? Here, it might be helpful to differentiate between external and internal perspectives. On the one hand, we invited exclusively eminent members of the historical profession who, in one way or another, all not only managed to make a successful living out of their scholarly practice but also left behind very obvious traces in their respective fields by introducing different forms of innovation. From such a perspective, and given the current opportunities for employment for young historians, their laments about having failed may sound unjustified, particularly since - ironically enough - the institutional success of the "'68ers of historiography" and their intellectual project has made the field of history so much more competitive. Thus, viewed from the outside, these are all very successful scholars. On the other hand, the majority of participants either express this sense of failure or disappointment at some point in their career, or consider themselves as outsiders. Even Pierre Nora, much to our surprise, does so by asserting that he was marginal with regard to the university establishment, and the same holds true, in other contexts, for Carl E. Schorske and Natalie Zemon Davis. ${ }^{17}$

Self-fashioned marginality, then, as a leitmotiv of the entire genre? The issue is relevant not only because it touches on a recurrent stereotype of the 1968 generation, as one reluctant to identify itself with power and authority. It is also significant because it shows that the question of power is still a concern of this generation, which measures its accomplishments not merely by professional success and academic recognition, but also by the type and extent of the change that it has succeeded in producing. It may happen that some historians are well known for their work and have for many years been esteemed members of the academic establishment; their impression, however, is that academia as a whole has not been deeply transformed by their efforts, and that crucial occasions and possibilities for real change in both culture and society have been lost. This impression of loss goes together with a sense of the end of an era. In her contribution, Barbara Taylor even speaks of the "the end of utopia." From a third perspective, then, this selfperceived marginality was in fact not untrue at some, even if now surpassed, points of their careers. All of them broke new ground, i.e. they achieved something considered unusual or 
unconventional at a given time, and hence subsequently earned a reputation for innovation and progress, when their various approaches had already moved further towards the center of historiography. In his presentation, for example, Pierre Nora emphasized how his double identity had allowed him to pursue risky, subsequently enormously influential projects such as the multi-volume project Lieux de mémoire: as an academic historian, he might have tried out the idea in a single book; as an editor and publisher, not at all.

"Is historical writing just a writing of the self, no matter how hard we try to respect the texts the past has bequeathed to us?"18 Is there a central element of Gegenübertragung (to use the respective psychoanalytical term) in any historiography? And if so, how are self-fashioning and self-realization achieved through the writing of history? Antonis Liakos especially considers this possibility very seriously. It is obvious that any ego-histoire derives its tension from the objectivity-subjectivity contrast at stake. The former, in particular, has long been at the core of debate: objectivity both as a concept and ideal were already challenged by Max Weber a century ago, and even if he went on to condemn most vehemently what he considered the constant mixing of "facts" and "opinion" ("die stete Vermischung wissenschaftlicher Erörterung der Tatsachen und wertender Raisonnements"), he simultaneously pleaded for the complete disclosure of all values and ideals. ${ }^{19}$ A very similar, heightened self-awareness is required of every ego-historien which then hopefully results in self-liberating effects. Thus, ego-histoire is the exact opposite of histoire totale, while - quite ironically - the level of completeness and depth of insight could not be much higher, in the smallest possible unit of study, with the expert being the subject matter and vice versa.

The issue of subjectivity seems still more complex in this context: First of all, by asking for the highest level of subjectivity possible ego-histoire automatically demonstrates "the necessarily subjective dimension of all history-making." ${ }^{20}$ Moreover, the fact that all these (progressive) historians immediately understood the relevance of the question we posed clearly has to do with their own interest in subjectivity and manifold attempts to write the subject back into history and historiography from the early 1980s onwards; this is especially obvious in the case of Lutz Niethammer. This general flight from the tone of objectivity is usually referred to as "le retour du sujet." Other, more traditionally oriented and less theoretically interested historians might not have seen the legitimacy of our question in the first place.

What, then, is it that actually happens in an ego-histoire and why does it constitute such an unusual and challenging exercise? John Brewer, for instance, called his the strangest paper he had ever been asked to give. Only here, the classical scholarly motto "de nobis ipsis silemus" (Francis Bacon) is simultaneously inverted: the strict separation between ego and work, normally meant to guarantee neutrality and the supraindividual applicability of the results obtained by applying the so-called scientific method, is deliberately and completely eliminated, and the ego's importance for work made the central theme itself. Three different histories merge in any ego-histoire: a personal life-past, a social, much more encompassing historical past, and a 
historiographical-professional past, including the contingent conditions of its production. In retrospect, many different choices and decisions have to be explained and justified - choices which include those of arriving at a particular subject, writing its history, and doing this in a particular way. Thus, every ego-historien cannot but disclose his or her personal concept of history and historiography alike within a triangle of questions: What is history all about? Does it matter at all? And how should it be written? The historian is forced to locate his or her position as precisely as possible and consequently reveal all those meta-historical assumptions that are always present, but too often remain well hidden. The challenge of ego-histoire lies precisely in the need to create the subject matter and simultaneously interpret it in one and the same essay, requiring control of both proximity to and distance from oneself in writing.

Finally, the question of terminology. Among the multiplicity of varying terms found in use such as "moi-histoire" (Jules Michelet), "Autoergographie" (Sigfrid Steinberg), "ego-histoire," "EigenGeschichte" or simply "auto-portrait," "self-portrait" or "Selbstdarstellung" - all of different origins and only loosely connected through emphasis on the metahistorical - we decided to keep the label "ego-histoire" and to maintain Pierre Nora's contribution in French as a sign that ours is a European enterprise, and that the English language has not yet overwhelmed every other form of expression. We believe that our "European Ego-histoires," however, do not simply consist in an attempt at replicating Nora's experiment in a different laboratory with another setting and a more heterogeneous sample. Rather, we intend to stimulate the rethinking, widening and reapplication of this concept to an international sample to set the stage for further analyzing patterns of selfperception, of the historian's relation with the public, and of the importance of life and the self in the writing of history. We are convinced that our decision to keep the label but to simultaneously revise the concept in a European framework demonstrates its enduring fruitfulness for the present and future alike. An observer of things in flux the historian may well be, but always a participating one.

We would like to express our sincere thanks to those without whom this enterprise could not have been realized: the eight authors for accepting our invitation; the respective audiences for their lively interest and enthusiastic participation; the Department of History and Civilization at the European University Institute in Florence for providing both the necessary intellectual context and material funds; Marta Craveri and others for organizational help in the very early stages of this enterprise; Sergio Amadei for administrative assistance; Nicky Owtram for meticulous language corrections; and, last but not least, Pothiti Hantzaroula for her excellent work as a member of Historein's editorial board.

Luisa Passerini and Alexander C. T. Geppert 
${ }^{1}$ Edward Hallett Carr, What is History? The George Macaulay Trevelyan Lectures delivered in the University of Cambridge January-March 1961. London: Macmillan, 1961, pp. 34-8.

${ }^{2}$ Pierre Nora (ed.), Essais d'ego-histoire. Paris: Gallimard: 1987, here pp. 5-7. Subsequently, the seven contributions were discussed by the Annales' next generation, with Arlette Farge, Jacques Revel and Henry Rousso among the six reviewers. Cf. Autour de l'ego-histoire, Le Débat, 49 (1988), pp. 122-40.

${ }^{3}$ Many of these texts are analyzed in Jeremy D. Popkin, "Ego-histoire and Beyond. Contemporary French Historian-Autobiographers," French Historical Studies, 19 (1996), pp. 1139-67. Idem, "Historians on the Autobiographical Frontier," American Historical Review, 104 (1999), pp. 725-48.

${ }^{4}$ Günter Niggl, Geschichte der deutschen Autobiographie im 18. Jahrhundert: Theoretische Grundlegung und literarische Entfaltung. Stuttgart: Metzler, 1977, pp. 14-26, esp. pp. 21-4.

${ }^{5}$ Sigfrid Steinberg (ed.), Die Geschichtswissenschaft der Gegenwart in Selbstdarstellungen. 2 vols. Leipzig: Felix Meiner, 1925/26. Cf. Ekkehard Klausa, "Vom Gruppenbewußtsein akademischer Subkulturen: Deutsche Fakultäten um 1900. Ein inhaltsanalytischer Vorstoß in wissenschaftssoziologischer Absicht," Kölner Zeitschrift für Soziologie und Sozialpsychologie, 33 (1981), pp. 329-44. For a number of contemporary, mostly enthusiastic reviews see the appendix to the last volume published in that series: Felix Meiner (ed.), Volkswirtschaftslehre in Selbstdarstellungen. Vol. II. Leipzig: Felix Meiner, 1929.

${ }^{6}$ Nikolaus Grass (ed.), Österreichische Geschichtswissenschaft der Gegenwart in Selbstdarstellungen. 2 vols. Innsbruck: Wagner, 1950/51; here vol. I, pp. VIllf. Cf. in this context Albert Müller, "Alte Herren/Alte Meister: 'Ego-Histoire' in der österreichischen Geschichtswissenschaft. Eine Quellenkunde," Österreichische Zeitschrift für Geschichtswissenschaften, 4 (1993), pp. 120-33.

${ }^{7}$ Fernand Braudel, "Personal Testimony," Journal of Modern History, 44 (1972), pp. 448-67, here p. 448. Nora, Essais d'ego-histoire, p. 5.

${ }^{8}$ See, for example, the "autobiographical anecdote" at the beginning of Eric Hobsbawm's Overture in his The Age of Empire 1875-1914 (New York: Vintage, 1987, pp. 1-5) or David Cannadine's autobiographical appendix entitled "An Imperial Childhood?" to this recent Ornamentalism. How the British Saw Their Empire (Harmondsworth: Penguin, 2001, pp. 181-99) in which he makes himself his own test-case.

${ }^{9}$ For full (and further) references in all categories mentioned here, cf. the respective sections in the detailed bibliography included at the end of this volume, pp. 173-178.

${ }^{10}$ The first ten of these lectures (1983-1993) have been published in a volume edited by Douglas Greenberg and Stanley N. Katz, The Life of Learning. The Charles Homer Haskins Lectures of the American Council of Learned Societies. New York: Oxford University Press, 1994. For a complete list cf. http://www.acls.org./ophaskin.htm.

${ }^{11}$ Peter Alter (ed.), Out of the Third Reich. Refugee Historians in Postwar Britain. London/New York: I. B. Tauris, 1998. Rüdiger Hohls, Konrad H. Jarausch and Jens Hacke (eds.), Versäumte Fragen: Deutsche Historiker im Schatten des Nationalsozialismus. Stuttgart: Deutsche Verlags-Anstalt, 2000.

12 For complete indices, cf. http://www.univie.ac.at/Wirtschaftsgeschichte/0eZG/index.html and http://chnm.gmu.edu/rhr/rhrindx6.htm\#top respectively. Some of the interviews were published in MARHO: The Radical Historians Organization (ed.), Visions of History. Interviews with E. P. Thompson, Eric Hobsbawm, Sheila Rowbotham, Linda Gordon, Natalie Zemon Davis, William Appleman Williams, Staughton Lynd, David Montgomery, Herbert Gutman, Vincent Harding, John Womack, C. L. R. James, Moshe Lewin. New York: Pantheon Books, 1984, and Roger Adelson (ed.), Speaking of History. Conversations with Historians. East Lansing: Michigan State University Press, 1997. 
${ }^{13}$ Cf. http://ihr.sas.ac.uk/publications/vidinfo.html. Some of these interviews are described, reviewed and analyzed in more detail in Roger Adelson and Russell Smith, "Videotaped Interviews with British Historians, 1985-1998," Albion, 31 (1999), pp. 257-68.

${ }^{14}$ Interview with William H. McNeill, in: Adelson, Speaking of History, p. 165.

${ }^{15}$ The same happened to Nora, who was unable to convince Michel de Certeau, Paul Veyne or François Furet to participate. Cf. Nora, Essais d'ego-histoire, p. 362, fn. 2.

${ }^{16}$ Klausa, pp. 340-2.

${ }^{17}$ Carl E. Schorske, for instance, speaks of his double "marginal identity" while (the Jewish, female, Leftist) Natalie Zemon Davis reflects upon her "lifelong ambivalence about centers" that made her "trying to write outsiders into history: workers, women, Jews, Amerindians, Africans [...] as if I were engaged in some rescue mission over and over again." Cf. Carl E. Schorske, A Life of Learning. Charles Homer Haskins Lecture for 1987. New York, NY: American Council of Learned Societies, 1987, p. 3, and Natalie Zemon Davis, A Life of Learning. Charles Homer Haskins Lecture for 1997. New York, NY: American Council of Learned Societies, 1997, pp. 17, 23f.

${ }^{18} \mathrm{Ibid}$. Arthur Mitzman, "Historische Identität und die Identität des Historikers," in Hedwig Röckelein (ed.), Biographie als Geschichte. Tübingen: Edition diskord, 1993, pp. 89-116, here p.100.

${ }^{19}$ Max Weber, "Die 'Objektivität' sozialwissenschaftlicher und sozialpolitischer Erkenntnis" [1904], idem, Gesammelte Aufsätze zur Wissenschaftslehre. 7th ed. Tübingen: Mohr, 1988, pp. 146-214, here p. 157. Peter Novick, That Noble Dream. The "Objectivity Question" and the American Historical Profession. Cambridge: Cambridge University Press, 1988.

${ }^{20}$ Paul John Eakin, Touching the World. Reference in Autobiography. Princeton, NJ: Princeton University Press, 1992, p. 178. 